\title{
Correlation between Cesarean Delivery and Neonatal Morbidity
}

\author{
Msc. Ma. Etleva Rustami ${ }^{1}$, Dr. Nikita Manoku ${ }^{2}$, Dr. Klodiana Poshi ${ }^{3}$, Dr. Albana Cela ${ }^{4}$, Dr. Alketa Hoxha ${ }^{5}$ \\ ${ }^{1,3,4,5}$ University of Medicine of Tirana Albania \\ ${ }^{2}$ Department of Obstetric - Gynecology
}

\begin{abstract}
This study shall include all births concluded in the intensive care unit during 2013-14, carried out at "Mbretëresha Geraldinë" University Hospital Center of Obstetrics and Gynecology, Tirana. The study is retrospective. The number of babies involved is 629, of which 154 (24.5\%) were normal deliveries and 475 (75.5\%) were C-section ones. According to the results, it is clearly noticed a considerable growth of the number of $C$-section deliveries which have been transferred at the intensive care unit. The prevalence of serious conditions (problematic diagnosis) is much higher among $C$-section delivery (44.4\%) versus vaginal delivery (18.8\%\%) and this difference is statistically highly significant. $(P<0.001)$.
\end{abstract}

Keywords: caesarean section, vaginal delivery, neonatal morbidity.

\section{Introduction}

Caesarean section delivery is defined as delivery of the fetus through incision of abdominal wall (laparotomy) and uterine wall (hysterectomy). This definition does not include the extraction of fetus from the abdominal cavity in case of uterus rupture or in case of an abdominal pregnancy. In some cases and more often as a result of urgent complications like uncontrolled bleeding, abdominal hysterectomy is indicated after birth. In the event that hysterectomy is done after birth by caesarean section, it is called cesarean hysterectomy. If done right after vaginal delivery, it is called postpartum hysterectomy. (Fig 1)

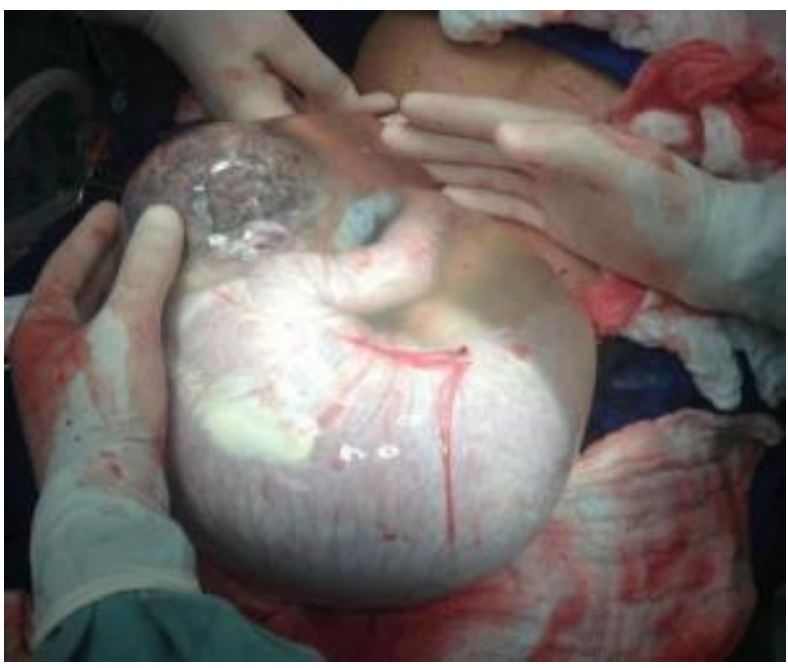

Figure 1: Baby born by caesarean section

The origin of the term "caesarean section" is dark and three main possible explanations have been suggested. First, according to the legend, Julius Cesar was born that way and consequently the procedure has become known as caesarean section. However there are some circumstances that do not support the explanation in question. Caesar's mother lived for many years after his birth in $100 \mathrm{BC}$, while until the $17^{\text {th }}$ century this type of surgery was invariably fatal. Secondly, the operation, conducted both in living and dead people, is not mentioned by any medical document before the Middle Ages.

Caesarean section is the most common surgical procedure used by women in the US (Trimble 2009). The optimal rate of caesarean section recommended by the World Health Organization (WHO) is 10 to $15 \%$, while in the USA since 2010 it is $32.8 \%$ (Gibbons 2010) (Fig 2). This number has minimally changed in the recent years, despite the increased awareness about cesarean statistics. Certified professional midwives who take care of women are trying to avoid this high figure of cesarean incisions making women choose themselves natural delivery at hospital. Thus, their chances to undergo a caesarean section have dramatically decreased, although it is impossible to be eliminated.

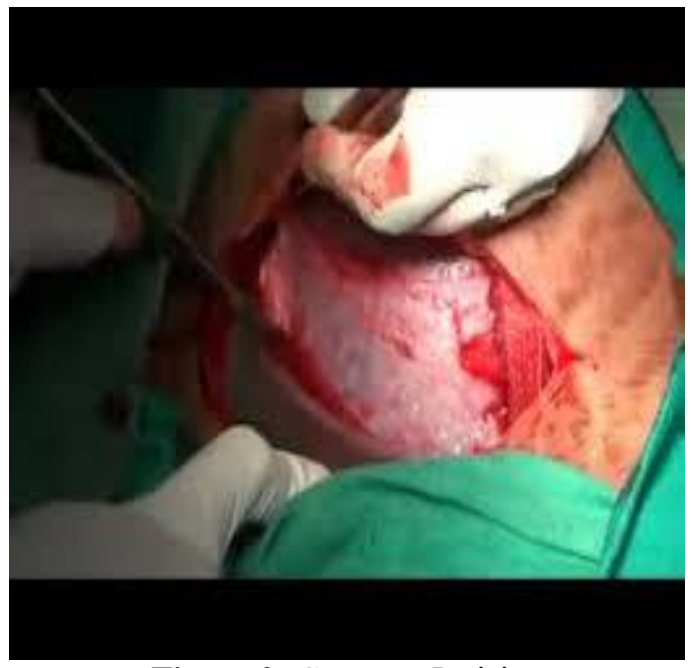

Figure 2: Cesarean Incision

Opinions differ on the benefits of achieving an empowering birth experience. For many women, giving birth is a transforming life event, one that is anticipated for months or even years. Unexpected events can cause postpartum depression or posttraumatic stress disorder ( el Alcorn et 2010. Allen 1998; Griebenoë 2006; Smith et al 2000). 


\section{International Journal of Science and Research (IJSR) \\ ISSN (Online): 2319-7064 \\ Index Copernicus Value (2013): 6.14 | Impact Factor (2014): 5.611}

Evidence shows that the majority of women who have a cesarean have a less-than-satisfactory childbirth experience

(Smith, Plaat and his colleagues).

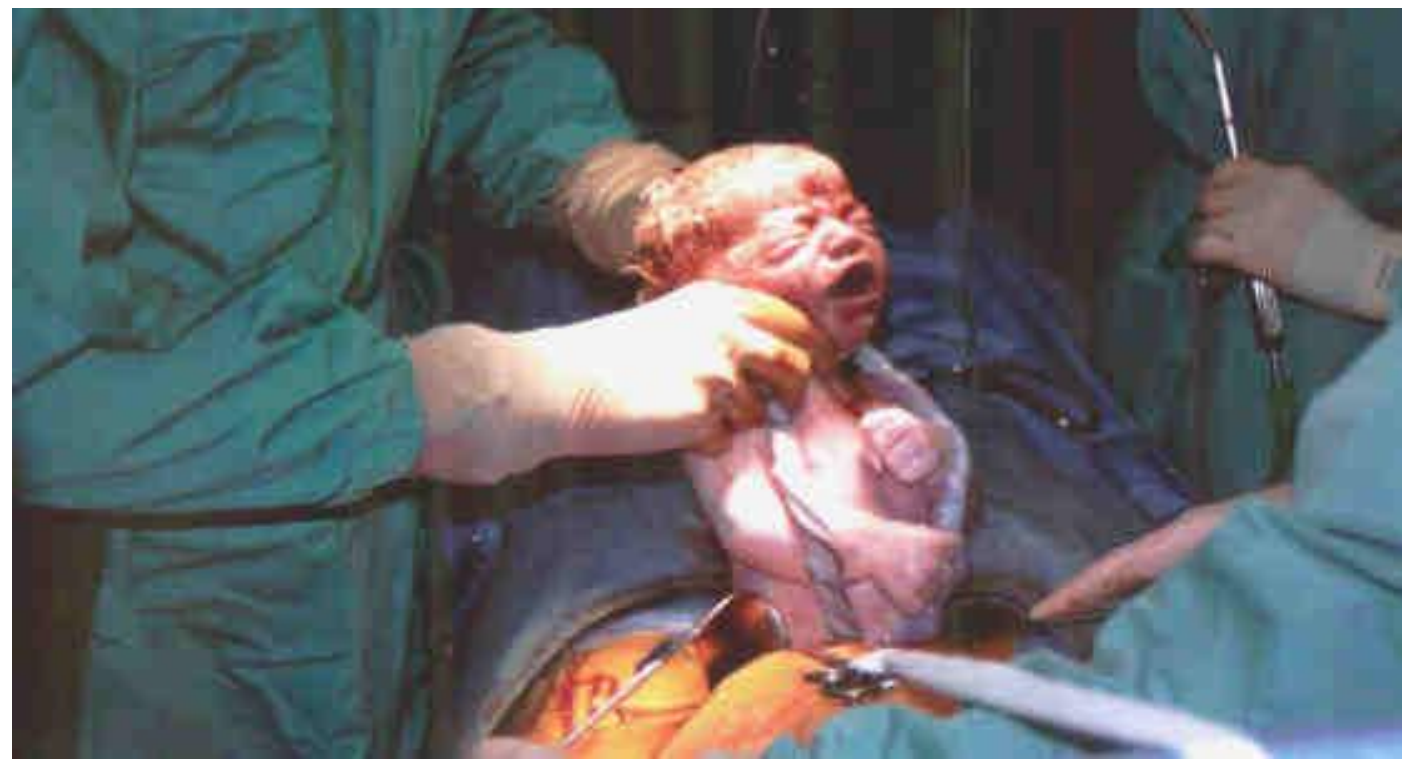

Figure 3: Cutting the umbilical cord

Here are some of the reasons why $\mathrm{C}$-section birth rate has increased. The reasons why the birth rate by cesarean incision quadrupled between 1965 and 1988 and its continued growth is not very clear, but we have provided some explanations as follows:

1) Women who wish to have fewer children. In this way, a greater percentage of mothers are nulliparous and it has been observed a growing tendency in them to give birth by caesarean section.

2) The average age of pregnant mothers is growing, even at women of not very young age, especially nulliparous; it has been observed a growing tendency to give birth by caesarean section.

3) The use of electronic fetal monitoring has increased. This technique is associated with such events as the fall of fetal heartbeat rhythm and its overestimation may be followed by a growth of caesarean section.

4) The vast majority is related to abnormal fetal presentation and therefore subject to caesarean section.

5) Complaints on malpractice and consequently judicial cases have significantly contributed to the growth of the actual number of births by caesarean section.

6) More than a decade ago, it was reported that the failure of birth by caesarean section may lead to neonatal neurological problems or cerebral paralysis. This was the dominant obstetrical demand in the United States (Independent Practice Association, 1992).

7) Specifically, in 2001, neonate brain damage was the claim holding responsible the obstetrician-gynecologist in $40 \%$ of all forensic indemnity. (Independent Practice Association, 2002).

8) Some reasons that enable the choice of cesarean birth are related to the concerns about the damage of pelvis associated with vaginal delivery (Nygaard and Cruikshank, 2003).

9) Also caesarean section is usually performed even by a large part of women who willfully choose to undergo
Patient choice for cesarean delivery

the caesarean section (Harer, 2000) They play a key role in taking this decision, which is about giving birth and receiving obstetric care. The reason of their decision for caesarean section delivery is that in this way they feel safer both for themselves and their baby. Currently it is assumed that the issue is highly controversial.

10) The reasons for this choice include avoiding pelvis damage compared to vaginal delivery, risk reduction with regards to the damage of fetus and the comfort (Al - myftiu and colleagues, 1997)

\section{Purpose}

The purpose of this study is to identify the impact of caesarean section delivery versus vaginal delivery, the risks and benefits, and neonate morbidity.

\section{Objectives}

- Birth impact by caesarean section in neonatal morbidity.

- Birth impact by caesarean section in increasing the number of hospital days.

\section{Material and Methods}

\section{Population under study}

To achieve the objectives, a retrospective study has been conducted observing and studying the growing number of births by caesarean section in years. Information for the study has been obtained from the patient card database at "Mbretëresha Geraldinë" Obstetric and Gynecological University Hospital, Tirana, which is responsible for all admissions at the institution.

The time period covers the data of births over a 1 year period, 2014. The study started in September 2012 until June 2015. The study included women who came to this institution for the birth procedure and for receiving proper assistance and care. 


\section{International Journal of Science and Research (IJSR) \\ ISSN (Online): 2319-7064 \\ Index Copernicus Value (2013): 6.14 | Impact Factor (2014): 5.611}

\section{Data Collection}

Files of this institution were studied and they include women who had given birth at "Mbretëresha Geraldinë" Obstetric and Gynecological University Hospital. It also included babies transferred at the intensive care unit by mothers who had given caesarean section and vaginal deliveries. Their data included pregnancy age, entry diagnosis, oxygen therapy, duration of stay, method of delivery. The study is a cross-sectional one and its population is patients after giving birth at our hospital. The samples of patients under the study are of non probability nature.

\section{Statistical Analysis of Data}

The study is of retrospective type, with two components:

a) Descriptive: This component refers to the description and evaluation of the situation and the division by delivery method, clinical classification and babies that show various problems.

b) Analytical: This component refers to the evaluation of the connection (association) of the risk factors related to babies born by caesarean section.

The calculation is based on standard indicator. There are used descriptive statistical methods, $\chi^{2}$ tests and Binary Logistic Regression tests. The OR probability ratio is used to assess the association among variables. Point ratings have been associated with $95 \%$ confidence interval on the analysis of cards data conducted to meet the proper objectives of our study. Tables and graphs have been used for data visualization. The value of $\mathrm{p}<0.05$ was considered statistically significant.

\section{Results}

In our paper it is noticed that in total there are 629 records, of which 154 (24.5\%) were normal delivery (vaginal), 475 $(75.5 \%)$ were caesarean section, as shown in the graph below:

Presented in tab. no. 1 and fig. 3
Table 1: The number of neonates depending on the delivery method

\begin{tabular}{|c|c|c|c|c|c|}
\hline \multicolumn{7}{|c|}{ Sexio_Cesarea } \\
\hline \multirow{2}{*}{ Valid } & & Frequency & Percent & Valid Percent & $\begin{array}{c}\text { Cumulative } \\
\text { Percent }\end{array}$ \\
\hline \multirow{2}{*}{ Jo } & 154 & 24.5 & 24.5 & 24.5 \\
\cline { 2 - 6 } & Po & 475 & 75.5 & 75.5 & 100 \\
\cline { 2 - 6 } & Total & 629 & 100 & 100 & \\
\hline
\end{tabular}

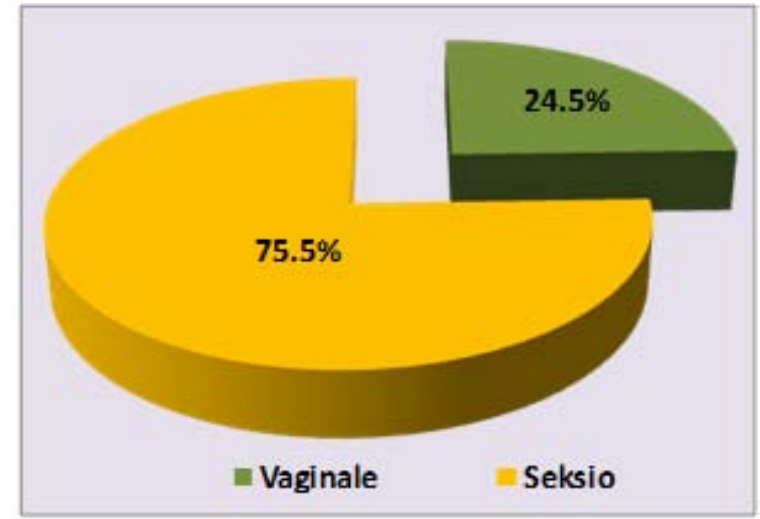

Figure 3: Percentage no of the two birth methods

2. Comparison of average birth weight between the two groups (vaginal delivery vs. caesarean section)

During the analysis in study groups of neonate average weight was observed that:

The average weight at birth is much higher in vaginal births (average value: $2866 \pm 730$ ) compared to babies born by caesarean section (average value: $2567 \pm 898$ ), and this difference is highly statistically significant $(\mathrm{P}<0.001)$, as expressed in the following table (student's t-test): (tab 2, graph 2)

Table 2: Average weight of babies and delivery method

\begin{tabular}{|c|c|c|c|c|c|}
\hline \multicolumn{6}{|c|}{ Group Statistics } \\
\hline & Sexio_Cesarea & $N$ & Mean & $\begin{array}{c}\text { Std. } \\
\text { Deviation }\end{array}$ & $\begin{array}{c}\text { Std. Error } \\
\text { Mean }\end{array}$ \\
\hline Pesha_lindjes & Jo & 154 & 2866.17 & 729.911 & 58.818 \\
\hline & Po & 475 & 2566.66 & 897.659 & 41.187 \\
\hline
\end{tabular}

Table 2.1: Comparison of average birth weight between the two groups (vaginal delivery vs. caesarean section)

Independent Samples Test

\begin{tabular}{|c|c|c|c|c|c|c|c|c|c|c|}
\hline & \multicolumn{2}{|c|}{$\begin{array}{l}\text { Levene's Test for } \\
\text { Equality of Variances }\end{array}$} & \multicolumn{7}{|c|}{ t-test for Equality of Means } \\
\hline & & \multirow[b]{2}{*}{$\mathrm{F}$} & \multirow[b]{2}{*}{ Sig. } & \multirow[b]{2}{*}{$t$} & \multirow[b]{2}{*}{$d f$} & \multirow[b]{2}{*}{ Sig. (2-tailed) } & \multirow{2}{*}{$\begin{array}{c}\text { Mean } \\
\text { Diff erence }\end{array}$} & \multirow{2}{*}{$\begin{array}{l}\text { Std. Error } \\
\text { Diff erence }\end{array}$} & \multicolumn{2}{|c|}{$\begin{array}{l}\text { 95\% Confidence } \\
\text { Interval of the } \\
\text { Difference }\end{array}$} \\
\hline & & & & & & & & & Lower & Upper \\
\hline Pesha_lindjes & $\begin{array}{l}\text { Equal variances } \\
\text { assumed }\end{array}$ & 8.878 & .003 & 3.757 & 627 & .000 & 299.506 & 79.724 & 142.947 & 456.064 \\
\hline & $\begin{array}{l}\text { Equal variances } \\
\text { not assumed }\end{array}$ & & & 4.171 & 315.361 & .000 & 299.506 & 71.805 & 158.228 & 440.783 \\
\hline
\end{tabular}

Analysis of the two groups, vaginal vs. caesarean section, about the duration of hospital stay is comparatively very significant. Average stay is much higher among caesarean section deliveries (8.0 \pm 8.2$)$ compared to vaginal delivery $(5.3 \pm 3.9)$ and this difference is highly statistically significant
( $\mathrm{P}<0.001$ ), as expressed in the following table (student's ttest). This is reflected in Table 4 


\section{International Journal of Science and Research (IJSR) \\ ISSN (Online): 2319-7064}

Index Copernicus Value (2013): 6.14 | Impact Factor (2014): 5.611

Table 4: Comparison of average stay between the two groups (vaginal delivery vs. caesarean section)

Group Statistics

\begin{tabular}{|ll|r|r|r|r|}
\hline & & & & \multicolumn{1}{c|}{ Std. Error } \\
Sexio Cesarea & $\mathrm{N}$ & \multicolumn{1}{c|}{ Mean } & Std. Deviation \\
\hline Dite_qendrimi & Jo & 154 & 5.31 & 3.938 & .317 \\
& Po & 475 & 8.02 & 8.231 & .378 \\
\hline
\end{tabular}

Average stay is much higher among caesarean section

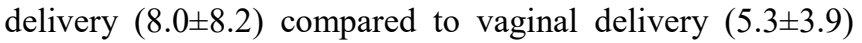
and this difference is highly statistically significant
$(\mathrm{P}<0.001)$ as expressed in the following table (student's ttest).

Table 5: Student's t-test in the calculation of average stay of babies in the intensive care unit

\begin{tabular}{|c|c|c|c|c|c|c|c|c|c|c|}
\hline \multicolumn{11}{|c|}{ Independent Samples Test } \\
\hline & & \multicolumn{2}{|c|}{$\begin{array}{l}\text { Levene's Test for } \\
\text { Equality of Variances }\end{array}$} & \multicolumn{7}{|c|}{ t-test for Equality of Means } \\
\hline & & \multirow[b]{2}{*}{$\mathrm{F}$} & \multirow[b]{2}{*}{ Sig. } & \multirow[b]{2}{*}{$t$} & \multirow[b]{2}{*}{ df } & \multirow[b]{2}{*}{ Sig. (2-tailed) } & \multirow{2}{*}{$\begin{array}{c}\text { Mean } \\
\text { Difference }\end{array}$} & \multirow{2}{*}{$\begin{array}{l}\text { Std. Error } \\
\text { Diff erence }\end{array}$} & \multicolumn{2}{|c|}{$\begin{array}{c}95 \% \text { Confidence } \\
\text { Interval of the } \\
\text { Diff erence }\end{array}$} \\
\hline & & & & & & & & & Lower & Upper \\
\hline Dite_qendrimi & $\begin{array}{l}\text { Equal variances } \\
\text { assumed }\end{array}$ & 27.869 & .000 & -3.933 & 627 & .000 & -2.705 & .688 & -4.056 & -1.355 \\
\hline & $\begin{array}{l}\text { Equal variances } \\
\text { not assumed }\end{array}$ & & & -5.484 & 542.218 & .000 & -2.705 & .493 & -3.674 & -1.736 \\
\hline
\end{tabular}

Comparison of the average pregnancy age between the two groups (vaginal delivery vs. caesarean section)

As shown in Table no 6, the average pregnancy age is much higher in vaginal delivery $(35.9 \pm 3.7)$ compared to caesarean section births $(37.3 \pm 2.6)$ and this difference is highly statistically significant $(\mathrm{P}<0.001)$, as expressed in the following table (student's t-test):

Table 6: Comparison of the average pregnancy age between the two groups (vaginal delivery vs. caesarean section)

\begin{tabular}{|c|c|c|c|c|c|c|c|c|c|c|}
\hline \multicolumn{11}{|c|}{ Independent Samples Test } \\
\hline & & \multicolumn{2}{|c|}{$\begin{array}{l}\text { Levene's Test for } \\
\text { Equality of Variances }\end{array}$} & \multicolumn{7}{|c|}{ t-test for Equality of Means } \\
\hline & & \multirow[b]{2}{*}{$\mathrm{F}$} & \multirow[b]{2}{*}{ Sig. } & \multirow[b]{2}{*}{$t$} & \multirow[b]{2}{*}{ df } & \multirow[b]{2}{*}{ Sig. (2-tailed) } & \multirow{2}{*}{$\begin{array}{c}\text { Mean } \\
\text { Difference }\end{array}$} & \multirow{2}{*}{$\begin{array}{l}\text { Std. Error } \\
\text { Diff erence }\end{array}$} & \multicolumn{2}{|c|}{$\begin{array}{l}95 \% \text { Confidence } \\
\text { Interval of the } \\
\text { Difference }\end{array}$} \\
\hline & & & & & & & & & Lower & Upper \\
\hline Mosha_barres & $\begin{array}{l}\text { Equal variances } \\
\text { assumed }\end{array}$ & 17.147 & .000 & 4.308 & 627 & .000 & 1.389 & .322 & .756 & 2.022 \\
\hline & $\begin{array}{l}\text { Equal variances } \\
\text { not assumed }\end{array}$ & & & 5.124 & 367.359 & .000 & 1.389 & .271 & .856 & 1.922 \\
\hline
\end{tabular}

Comparison of entry diagnosis between the two groups (vaginal delivery vs. caesarean section)

Table 7: Comparison of entry diagnosis between the two groups (vaginal delivery vs. caesarean section)

\begin{tabular}{|lr|r|r|r|}
\hline \multirow{2}{*}{} & \multicolumn{2}{|c|}{ Sexio } & \multicolumn{1}{|c|}{ Cesarea } & \multicolumn{1}{|c|}{ Total } \\
\cline { 2 - 4 } & \multicolumn{1}{|c|}{ Jo } & \multicolumn{1}{c|}{ Po } & \multicolumn{1}{c|}{389} \\
& 125 & 264 & 389 \\
& & $81.2 \%$ & $55.6 \%$ & $61.8 \%$ \\
\cline { 2 - 5 } & Gjendje e rende & 29 & 211 & 240 \\
& $18.8 \%$ & $44.4 \%$ & $38.2 \%$ \\
\hline Total & 154 & 475 & 629 \\
& $100.0 \%$ & $100.0 \%$ & $100.0 \%$ \\
\hline
\end{tabular}

The prevalence of serious conditions (problematic diagnosis) is much higher among caesarean section delivery (44.4\%) compared to vaginal delivery $(18.8 \%)$ and this difference is highly statistically significant $(\mathrm{P}<0.001)$, as expressed in the following table (chi-squared test and/or Fisher's exact test): 
International Journal of Science and Research (IJSR)

ISSN (Online): 2319-7064

Index Copernicus Value (2013): 6.14 | Impact Factor (2014): 5.611

\begin{tabular}{|c|c|c|c|c|c|}
\hline \multicolumn{6}{|c|}{ Chi-Square Tests } \\
\hline & Value & df & $\begin{array}{l}\text { Asymp. Sig. } \\
\text { (2-sided) }\end{array}$ & $\begin{array}{c}\text { Exact Sig. } \\
\text { (2-sided) }\end{array}$ & $\begin{array}{l}\text { Exact Sig. } \\
\text { (1-sided) }\end{array}$ \\
\hline Pearson Chi-Square & $32.273^{b}$ & 1 & .000 & & \\
\hline Continuity Correctiona & 31.198 & 1 & .000 & & \\
\hline Likelihood Ratio & 34.782 & 1 & .000 & & \\
\hline Fisher's Exact Test & & & & .000 & .000 \\
\hline $\begin{array}{l}\text { Linear-by-Linear } \\
\text { Association }\end{array}$ & 32.222 & 1 & .000 & & \\
\hline $\mathrm{N}$ of Valid Cases & 629 & & & & \\
\hline
\end{tabular}

\section{Discussions}

As seen from the above results, caesarean section delivery involves a greater risk in neonate morbidity compared to vaginal delivery $(\%)$. This conclusion is clearly described at ${\text { (Merc Manual })^{[3.5]}}$

The risk for the presence of various diagnoses, such as neonatal respiratory distress, leads to its treatment in an intensive care unit. ${ }^{[1.3,5.8]}$

Caesarean section delivery increases the duration of hospital stay, and as a consequence there is a longer care and observation from the medical personnel, including here physicians and nurses in podalic presentations where the risk on neonatal morbidity is higher ${ }^{[1.4 .7]}$.

Women that undergo caesarean section, despite of its their choice or it is predetermined by the medical staff which is independent from the demographic or clinical data, display twice as much risk for morbidity or death, including (death, hysterectomy, blood transfusion, admission to the intensive therapy ${ }^{[19.20 .21]}$ and display five times more the risk of postpartum infections than those with vaginal delivery [1,7,9.15]

\section{Conclusions}

Caesarean section neonates display a higher morbidity, which is a statistically significant value. They have a higher staying period, a lower weight although in accordance with the pregnancy age. Intensive care in this group requires attention from the medical staff

\section{References}

[1] Bazat e obstetrikes . O. GLIOZHENI , A. BIMBASHI , R. MOISIU , (21-obstetrika operative/219)

[2] J Obstet Gynecol India Vol. 59, No. 5 : September / October 2009 pg 413-423

[3] U. K. Collaborative ECMO Trial Group,. (1996). UK collaborative randomised trial of neonatal extracorporeal membrane oxygenation. Lancet, 348(9020), 75-82. http://www.sciencedirect.com/science/article/pii/S0140 673696041001

[4] SCHELLER dhe Nelson 1994

[5] Bartlett, R. H., Roloff, D. W., Cornell, R. G., Andrews, A. F., Dillon, P. W., \& Zwischenberger, J. B. (1985).
Extracorporeal-Circulation in Neonatal RespiratoryFailure - a Prospective Randomized Study. Pediatrics, 76(4), 479-487. http://pediatrics.aappublications.org/content/76/4/479.f ull.pdf+html

[6] Lien dhe bashkëpunëtorët (1995)

[7] Akademia Amerikane e Pediatrisë dhe Kolegji i gjinekologëve (2002)

[8] Als $\mathrm{H}^{1}$.Developmental care in the newborn intensive care unit. Curr Opin Pediatr. 1998 Apr;10(2):138-42

[9] Burrows et al, 2004

[10] Lydon - Rochelle et al (2000)

[11] Rajasekar and Hall (1997)

[12] Henderson et al, 2001.

[13] Cargnoni A, Piccinelli EC, Ressel L, Rossi D, Magatti M, Toschi I, Cesari V, Albertini M, Mazzola S, Parolini O.Conditioned medium from amniotic membranederived cells prevents lung fibrosis and preserves blood gas exchanges in bleomycin-injured mice-specificity of the effects and insights into possible mechanisms. Cytotherapy. 2014 Jan;16(1):17-32. doi: 10.1016/j.jcyt.2013.07.002. Epub 2013 Oct 1.

[14] Sumano-Ziga E, Veloz-Martínez MG, VázquezRodríguez JG, Becerra-Alcántara G, Jimenez Vieyra CR.[Scheduled hysterectomy vs. urgent hysterectomy in patients with placenta accreta in a high specialty medical unit].Cir Cir. 2015 Jul-Aug;83(4):303-8. doi: 10.1016/j.circir.2015.01.001. Epub 2015 Jun 23. Spanish.

[15] Rechia IC, Liberalesso KP, Angst OV, Mahl FD, Garcia MV, Biaggio EP.Intensive care unit: results of the Newborn Hearing Screening.Braz J Otorhinolaryngol. 2015 Oct 29. pii: S1808-8694(15)00182-2. doi: 10.1016/j.bjorl.2015.06.004. [Epub ahead of print]

[16] Khetan R, Hurley M, Spencer S, Bhatt JM Bronchopulmonary Dysplasia Within and Beyond the Neonatal Unit.Adv Neonatal Care. 2016 Feb;16(1):17-25. doi: 10.1097/ANC.0000000000000251

[17] Livingston and Passaro, 1990.

[18]Roberts CT, Owen LS, Manley BJ, Davis PG; Australian \& New Zealand Neonatal Network (ANZNN).High-flow support in very preterm infants in Australia and New Zealand.Arch Dis Child Fetal Neonatal Ed. 2015 Dec 17. pii: fetalneonatal-2015309328. doi: 10.1136/archdischild-2015-309328. [Epub ahead of print] 